\title{
FOS wt Allele
}

National Cancer Institute

\section{Source}

National Cancer Institute. FOS wt Allele. NCI Thesaurus. Code C52887.

Human FOS wild-type allele is located in the vicinity of $14 q 24.3$ and is approximately $3 \mathrm{~kb}$

in length. This allele, which encodes proto-oncogene protein c-fos, is involved in the regulation of transcription by RNA polymerase II. 